\title{
PENINGKATAN KUALITAS MINYAK GORENG BEKAS DENGAN MENGGUNAKAN ADSORBEN ARANG AKTIF DARI AMPAS TEBU YANG DIAKTIVASI DENGAN $\mathrm{NaCL}$
}

\author{
Zona Octarya, Adhitya Fernando
}

\author{
Program Studi Pendidikan Kimia UIN SUSKA Riau \\ Email; souvenirznoc@yahoo.co.id
}

\begin{abstract}
This study uses activated carbon from bagasse as adsorbent by $75 \mathrm{mg}$ in 200 grams of used cooking oil. Used oil is cooking oil that has been worn for 10 hours and comes from the restaurant industry. Activated carbon is made from leftover bagasse disposal is carbonized at a temperature of $600{ }^{\circ} \mathrm{C}$ for 2 hours and was activated by $\mathrm{NaCl}$ and $30 \%$ test quality with iodine adsorption test. The test results of iodine adsorption test on activated carbon bagasse is 795,56 mg $\mathrm{g}$ and has met the SNI standard. The results showed that the peroxide used cooking oil, oil despicing results, the results of neutralization and bleaching results using bagasse activated charcoal in a row is 10,12 $\mathrm{meq} / \mathrm{kg}, 8,62 \mathrm{meq} / \mathrm{kg}, 6,04 \mathrm{meq} / \mathrm{kg}$, and 3,93 meq/kg. While the results of the determination of free fatty acids (FFA) on used cooking oil, despicing results, the results of neutralization and bleaching results using bagasse activated charcoal in a row is 2,4\%,2,016\%,0,88\% and 0,49\%. The results of the determination of peroxide and free fatty acids (FFA) has not met the quality standard of cooking oil (SNI), but is able to improve the quality of cooking oil.
\end{abstract}

Keywords: used cooking oil, activated carbon, bagasse, batch systems, free fatty acids, peroxide value

\section{PENDAHULUAN}

Makanan yang digoreng dengan minyak goreng yang dipakai berulang-ulang tanpa batasan dan suhu yang tinggi menyebabkan meningkatnya angka peroksida dan kadar asam lemak bebas menjadi tinggi. Proses ini menghasilkan zat yang bersifat toksik (berefek racun) bagi manusia (Tarigan dkk, 2007). Selain itu, penggunaan minyak goreng secara berulangulang mengindikasikan lemahnya pengetahuan dan perhatian masyarakat terhadap keamanan pangan dan dampak buruknya.

Kemungkinan adanya aksi karsinogenik dalam minyak yang dipanaskan (pada suhu 300$350{ }^{\circ} \mathrm{C}$ ) dibuktikan dari bahan pangan berlemak yang teroksidasi yang dapat mengakibatkan pertumbuhan kanker dalam hati dan perubahan itu menyebabkan minyak goreng tidak layak lagi digunakan sebagai bahan untuk menggoreng makanan (Ketaren, 2005).

Kerusakan minyak akibat pemanasan suhu tinggi akan mengakibatkan keracunan dalam tubuh dan berbagai penyakit, misalnya diarhea, pengendapan lemak dalam pembuluh darah (arthero sclerosis), kanker dan menurunkan nilai cerna minyak. Solusi sederhana adalah mengganti minyak bekas pakai dengan minyak baru. Namun jika minyak goreng bekas tersebut dibuang, selain tidak ekonomis juga akan mencemari lingkungan (Buczek et all, 2008)

Sebanyak $49 \%$ dari total permintaan minyak goreng di Indonesia berasal dari rumah tangga dan sisanya untuk keperluan industri maupun restoran (Tri dkk, 2010). Maka dari itu, perlu dilakukan upaya-upaya untuk penanggulangan masalah minyak goreng bekas agar tidak semakin membahayakan kesehatan masyarakat, tidak mencemari lingkungan serta meningkatkan nilai ekonomis minyak bekas dengan cara yang baik dan aman.

Hingga saat ini sudah cukup banyak literatur yang mengupas tentang pemurnian minyak goreng bekas menggunakan karbon aktif. Diantaranya adalah: Penggunaan kulit pisang kepok (Musa Normalis) sebagai adsorben (Mulawarman, 2007). Penggunaan arang sekam padi IR 64 dan mampu menurunkan angka peroksida minyak kelapa tradisonal sampai dengan 84.4 \% (Wahyuni dkk, 2008). Penggunaan karbon aktif tempurung kelapa sebagai adsorben serta penggunaan adsorben zeolit alam (Widayat dkk, 2006). Penggunaan filter membran sebagai adsorben (Wulyoadi dkk, 2004). Pemurnian minyak goreng bekas dapat dilakukan dengan cara adsorpsi menggunakan karbon aktif. Zat warna dalam minyak akan 
diserap oleh permukaan adsorben dan juga menyerap suspensi koloid serta hasil degradasi minyak. Pada penelitian ini, minyak goreng bekas dimurnikan dan dilakukan peningkatan kualitasnya dengan menggunakan karbon aktif dari ampas tebu yang telah diaktivasi dengan $\mathrm{NaCl}$. Sistem adsorpsi dapat dilakukan dengan dua metode, yaitu metode kolom dan metode batch. Metode kolom dipandang lebih efektif karena kolom yang digunakan dapat diregenerasi kembali (Istighfaro, 2010). Sistem adsorpsi pada penelitian ini adalah metode batch menggunakan magnetic stirrer.

Pada dasarnya, karbon aktif dapat dibuat dari semua bahan yang mengandung karbon, baik karbon organik maupun anorganik dengan syarat bahan tersebut mempunyai struktur berpori. Kandungan karbon yang tinggi dalam ampas tebu menjadi dasar untuk memanfaatkannya sebagai karbon aktif (Wijayanti, 2010)

Pada penelitian ini karbon aktif dihasilkan dari aktivasi menggunakan $\mathrm{NaCl} . \quad \mathrm{NaCl}$ digunakan karena harganya relatif murah dan mudah didapat. Penggunaan karbon aktif dari ampas tebu sebagai adsorben pada pemurnian minyak goreng bekas juga telah pernah diteliti sebelumnya. Hasil pemurnian menunjukkan bahwa karbon aktif yang digunakan dapat menurunkan kadar asam lemak bebas dalam minyak goreng bekas. Penurunan kadar asam lemak bebas terbesar diperoleh dengan aktivasi kimia dengan perendaman $\mathrm{H}_{3} \mathrm{PO}_{4} 10 \%$ yang diaktivasi pada suhu $800{ }^{\circ} \mathrm{C}$ selama 120 menit (Wijayanti, 2009).

Penelitian ini diarahkan untuk mengembangkan bahan baku alternatif dalam pembuatan karbon aktif yang diaplikasikan sebagai adsorben pada pemurnian minyak goreng bekas. Karbon aktif dari ampas tebu yang diaktivasi dengan $\mathrm{NaCl}$ ini diharapkan dapat menjadi alternatif pilihan adsorben yang efektif, murah dan efisien serta dapat meningkatkan nilai ekonomis bahan.

Selain itu, dalam penelitian ini juga akan dikaji lebih lanjut mengenai efektifitas adsorpsi ampas tebu dalam peningkatan kualitas minyak goreng bekas dengan metode batch menggunakan magnetic strirrer. Sehingga diharapkan dapat menurunkan bilangan peroksida dan asam lemak bebas yang memenuhi Standar Nasional Indonesia (SNI).

\section{METODOLOGI PENELITIAN}

\section{Alat dan Bahan}

\section{Alat}

Seperangkat alat gelas, alumunium foil, tanur, oven, kertas saring, ayakan 100-120 mesh, mortar dan mortar, buret, statis, erlenmeyer, corong pisah, corong biasa, timbangan analitik, hot plate, cawan porselen, termometer, magnetic stirrer.

\section{Bahan}

Sampel yang digunakan dalam penelitian ini adalah: (1) Minyak goreng bekas diperoleh dari Rumah Makan Sinar Ampalu yang terletak di Jalan Garuda Sakti, Panam, Pekanbaru (2) Ampas tebu diperoleh dari usaha es tebu di kawasan Panam, Pekanbaru.

\section{Bahan Kimia}

$\mathrm{NaCl}, \mathrm{NaOH}$ (p.a), alkohol $95 \%$, indikator pp (p.a), kloroform (teknis), asam oksalat (p.a), natrium thiosulfat $\left(\mathrm{Na}_{2} \mathrm{SO}_{3}\right)$ (p.a), $\mathrm{HCl} 0.1 \mathrm{~N}$, larutan jenuh $\mathrm{KI}$ (p.a), larutan $\mathrm{I}_{2}$, larutan pati, $\mathrm{CH}_{3} \mathrm{COO}_{3}$ (p.a).

\section{Prosedur Penelitian}

\section{a. Preparasi ampas tebu}

Sebanyak $1 \mathrm{~kg}$ ampas tebu yang diperolah dari usaha es tebu terlebih dahulu dibersihkan dan dipotong halus. Ampas tebu yang sudah halus lalu dijemur dibawah sinar matahari selama 5-6 jam setiap harinya. Berat ampas tebu ditimbang setiap hari dan penjemuran dihentikan setelah diperoleh berat ampas tebu yang konstan.

\section{b. Pembuatan Arang Aktif Ampas Tebu}

75 gram ampas tebu yang telah kering dibungkus aluminium foil dan dimasukkan dalam cawan porselin lalu dimasukkan didalam tanur pada suhu $600{ }^{\circ} \mathrm{C}$ selama 2 jam. Kemudian arang yang terbentuk ditumbuk menggunakan mortar sampai halus dan diayak. Selanjutnya serbuk yang dihasilkan dicuci dengan air panas, 
kemudian dikeringkan dengan oven pada suhu $110^{\circ} \mathrm{C}$ selama $2 \mathrm{jam}$. Kemudian arang diaktivasi dengan direndam pada larutan $\mathrm{NaCl} 30 \%$ selama 24 jam, kemudian dikeringkan dalam oven 110 ${ }^{\circ} \mathrm{C}$ selama 4 jam. Dihasilkan sebanyak 45 gram arang aktif. Arang aktif yang dihasilkan kemudian dihaluskan dan disaring dengan ayakan 100 mesh.

\section{c. Pengujian Kualitas Arang Aktif (uji daya serap iodin)}

Dalam hal ini hanya akan dilakukan pengujian daya serap iodin karena besarnya daya serap iodin merupakan faktor utama untuk menentukan arang aktif terbaik yang akan digunakan sebagai adsorben pada pemurnian minyak goreng bekas.

Sampel kering sebanyak $\pm 0,25 \mathrm{~g}$ dimasukkan kedalam labu erlenmeyer yang dibungkus aluminium foil, ditambahkan $25 \mathrm{ml}$ larutan $\mathrm{I}_{2} 0,1 \mathrm{~N}$, kemudian dikocok selama 15 menit pada suhu kamar lalu disaring. Filtrat sebanyak $10 \mathrm{ml}$ dititrasi dengan larutan $\mathrm{Na}_{2} \mathrm{~S}_{2} \mathrm{O}_{3}$ $0,1 \mathrm{~N}$ hingga berwarna kuning muda lalu diberi beberapa tetes indikator amilum dan titrasi dilanjutkan sampai warna biru tepat hilang.

Ion yang diadsorbsi $\left(\frac{\mathrm{mg}}{\mathrm{g}}\right)=\frac{10-\frac{\mathrm{WXN}}{0,1 \mathrm{~N}} \times 12,693}{\mathrm{~W}} \times F p$

Keterangan:

$\mathrm{V}=$ Volume $\mathrm{Na}_{2} \mathrm{~S}_{2} \mathrm{O}_{3}(\mathrm{ml})$

$\mathrm{N}=$ Normalitas $\mathrm{Na}_{2} \mathrm{~S}_{2} \mathrm{O}_{3}(\mathrm{~N})$

12,69= Jumlah iod sesuai dengan 1

$\mathrm{ml}$ larutan natrium tiosulfat $0,1 \mathrm{~N}$

$\mathrm{W}=$ Berat karbon aktif (gram)

$\mathrm{Fp}=$ Faktor pengenceran

\section{d. Pemurnian Minyak Goreng Bekas}

\section{a. Penghilangan Bumbu (Despicing)}

Ditimbang sebanyak 250 gram minyak goreng bekas kemudian ditambahkan air dengan komposisi minyak:air (1:1), masukkan ke dalam beaker gelas 1 liter dan ditambahkan batu didih, selanjutnya dipanaskan pada suhu $100^{\circ} \mathrm{C}$ sampai air dalam beaker gelas tinggal setengahnya. Campuran didiamkan dalam corong pisah selama 1 jam, kemudian fraksi air pada bagian bawah dipisahkan sehingga diperoleh minyak bebas air, setelah itu dilakukan penyaringan dengan kertas saring untuk memisahkan kotoran yang tersisa.

\section{b. Netralisasi}

Minyak hasil despicing sebanyak 150 gram dipanaskan sampai temperatur $35^{\circ} \mathrm{C}$, kemudian ditambahkan $6 \mathrm{ml}$ larutan $\mathrm{NaOH} 16 \%$, diaduk campuran selama 10 menit pada temperatur 40 ${ }^{\circ} \mathrm{C}$, selanjutnya didinginkan selama 10 menit dan dipisahkan dengan cara disaring.

\section{c. Pemucatan (Bleaching)}

Sebanyak 100 gram minyak hasil netralisasi dipanaskan sampai suhu $70{ }^{\circ} \mathrm{C}$, ditambahkan serbuk karbon aktif kulit pisang sebanyak 75 mg, kemudian ditingkatkan suhunya sampai 100 ${ }^{\circ} \mathrm{C}, 5$ menit pertama diaduk menggunakan magnetik stirrer selama 60 menit. Selanjutnya disaring menggunakan kertas saring.

\section{e. Analisa Minyak Goreng}

\section{a. Penentuan Bilangan Peroksida}

Ditimbang sebanyak 5 gram tiap-tiap sampel. Sampel yang digunakan adalah minyak bekas sebelum perlakuan, minyak hasil despicing, netralisasi dan minyak hasil adsorbsi karbon aktif ampas tebu.

Sampel dimasukkan kedalam Erlenmeyer $250 \mathrm{ml}$, kemudian ditambahkan $30 \mathrm{ml}$ campuran asam asetat-kloroform dengan perbandingan (3:2). Campuran digoyang-goyang sampai terlarut semuanya, kemudian ditambahkan 0,5 $\mathrm{ml}$ larutan KI jenuh dan erlenmeyer dibuat tutup. Didiamkan 1 menit dan digoyang lagi, kemudian ditambahkan $30 \mathrm{ml}$ aquades. Selanjutnya dititrasi dengan natrium tiosulfat $\left(\mathrm{Na}_{2} \mathrm{~S}_{2} \mathrm{O}_{3}\right)$ $0.002 \mathrm{~N}$ sampai warna kuning hampir hilang. Kemudian ditambahkan larutan indikator amilum sebanyak 0,5 ml. Kemudian titrasi dilanjutkan sampai warna biru mulai hilang. Selanjutnya angka peroksida dinyatakan dalam mili-equivalen dari peroksida dalam setiap 1000 gr minyak.

Bil. peroksida $\left(\frac{m e q}{\mathrm{~kg}}\right)=\frac{(V s-V b) \times N \times 1000}{m}$

Keterangan:

$\mathrm{Vb}=$ Volume larutan $\mathrm{Na}_{2} \mathrm{~S}_{2} \mathrm{O}_{3}$ untuk titrasi blanko (ml) 
Vs $=$ Volume larutan $\mathrm{Na}_{2} \mathrm{~S}_{2} \mathrm{O}_{3}$ untuk titrasi sampel (ml)

$\mathrm{N}=$ Normalitas larutan $\mathrm{Na}_{2} \mathrm{~S}_{2} \mathrm{O}_{3}$ yang digunakan

$\mathrm{M}=$ berat sampel (gram)

\section{b. Penentuan Asam Lemak Bebas}

Ditimbang sebesar 14 gram minyak goreng dan dimasukkan ke dalam erlenmeyer $250 \mathrm{ml}$ alkohol $95 \%$ dan dipanaskan pada suhu $40{ }^{\circ} \mathrm{C}$, setelah itu ditambahkan $2 \mathrm{ml}$ indikator $\mathrm{pp}$, dilakukan titrasi dengan larutan $0.1 \mathrm{~N} \mathrm{NaOH}$ sampai muncul warna merah jambu dan tidak hilang selama 30 detik. Dihitung asam lemak bebas (\% FFA) dengan rumus di bawah ini:

$$
\% \text { FFA }=\frac{m l \mathrm{NaOH} \times M \mathrm{NaOH} \times \mathrm{BM}}{\text { Berat sampel } \times 1000} \times 100
$$

Keterangan:

\% FFA: Kadar asam lemak bebas

ml NaOH: Volume titran $\mathrm{NaOH}$

M NaOH: Molaritas larutan $\mathrm{NaOH}$ (mol/L)

BM: Berat molekul asam leak merek bimoli (asam lemak palmitat) $256 \mathrm{~g} / \mathrm{mol}$

\section{HASIL DAN PEMBAHASAN}

\section{A. Preparasi Ampas Tebu menjadi Karbon Aktif}

Ampas tebu yang akan digunakan harus diperhatikan kandungan airnya, kebersihan, dan ukuran. Kadar air ampas tebu hasil preparasi adalah $54 \%$. Proses dehihdrasi dilakukan dengan cara menguapkan kandungan air yang terdapat pada ampas tebu dibawah sinar matahari selama 5 hari. Untuk mengetahui kandungan air yang sudah teruapkan secara maksimal dilakukan proses penimbangan sampai diperoleh berat konstan.

Membersihkan ampas tebu cukup dilakukan dengan mengirai-ngirai, selanjutnya ampas tebu tersebut dipotong kecil dan cukup halus. Hal ini dilakukan dengan tujuan untuk memperluas permukaan sampel ampas tebu agar mempermudah proses karbonisasi (mengubah sampel ampas tebu menjadi arang) sehingga bahan-bahan aditif penyusun ampas tebu mudah terdekomposisi dan diperoleh hasil karbonisasi dalam bentuk karbonnya.

\section{B. Pembuatan Arang Aktif dari Ampas Tebu}

Proses pembuatan karbon aktif berlangsung tiga tahap, yaitu proses dehidrasi, proses karbonisasi dan proses aktivasi. Proses dehidrasi sudah dilakukan pada saat preparasi ampas tebu.

\section{Proses Karbonisasi}

Proses karbonisasi adalah proses penguraian selulosa menjadi unsur karbon dan pengeluaran unsur-unsur non karbon (Sudrajat, 2005). Proses ini dilakukan dengan cara ampas tebu yang telah kering dibungkus dengan alumunium foil serapat mungkin. Tujuan perlakuan ini adalah agar tidak terjadi kontak antara sampel ampas tebu dengan udara yang akan menghasilkan abu atau dengan kata lain agar ampas tebu yangmengandung karbon hanya terkarbonisasi dan tidak teroksidasi.

Tahap karbonisasi ini akan menghasilkan karbon yang mempunyai daya adsorpsi yang rendah, sehingga menyebabkan kapasitas adsorpsi juga rendah. Daya adsorpsi tersebut dapat diperbesar dengan cara perbaikan struktur pori melalui proses aktivasi.

\section{Proses Aktivasi}

Arang ampas tebu hasil karbonisasi terlebih dahulu ditumbuk sampai berbentuk serbuk. Perlakuan ini bertujuan untuk membuka pori dan memperbesar luas permukaan arang sehingga semakin banyak permukaan arang yang kontak dengan aktivator. Semakin banyak permukaan arang yang berinteraksi dengan adsorbat. maka semakin besar pula proses adsorpsi yang terjadi.

Pada penelitian ini, proses aktivasi dilakukan secara kimia yakni dengan cara merendam serbuk arang ampas tebu ke dalam larutan Natrium Klorida ( $\mathrm{NaCl}$ ) 30\% selama 24 jam. Jumlah perbandingan perendaman antara arang ampas tebu dengan zat aktivator adalah (1:4) agar seluruh arang terendam oleh zat aktivator sehingga proses aktivasi terjadi secara maksimal.

Penggunaan larutan $\mathrm{NaCl}$ sebagai aktivator kimia karena harganya sangat terjangkau dibanding dengan jenis aktivator lainnya dan 
aman terhadap lingkungan sehingga limbah yang dihasilkan tidak menyebabkan pencemaran lingkungan. Garam $\mathrm{NaCl}$ dalam fasa cair terdiri dari ion-ion positif dan ion-ion negatif yang tersusun secara acak, sehingga dalam fasa larutannya $\mathrm{NaCl}$ lebih stabil dalam keadaan ionnya yaitu dalam bentuk ion $\mathrm{Na}^{+}$dan $\mathrm{Cl}^{-}$. Garam yang terionisasi akan menarik molekulmolekul air disekitarnya dan peristiwa ini disebut dengan hidrasi. Unsur-unsur dari persenyawaan $\mathrm{NaCl}$ yang ditambahkan akan meresap ke dalam arang dan membuka permukaan yang mula-mula tertutup oleh komponen kimia yang lain.

Garam $\mathrm{NaCl}$ berfungsi sebagai dehyidrating agent dan membantu menggantikan tar, endapan hidrokarbon dan pengotor lainnya yang dihasilkan pada proses karbonisasi serta mengembangkan struktur rongga yang ada pada karbon, sehingga permukaan pori karbon yang dihasilkan memiliki luas permukaan adsorpsi yang besar. Luas permukaan yang besar ini akan mempengaruhi hasil adsorpsi yang didapatkan (Istighfaro, 2010).

Karbon aktif yang dihasilkan kemudian dikeringkan lagi dalam oven $110{ }^{\circ} \mathrm{C}$ selama 4 jam untuk menguapkan air yang terikat dalam pori-pori karbon. Kemudian ditumbuk sampai halus untuk memperbesar luas permukaan karbon aktif sehingga mampu menyerap lebih banyak.

\section{Pengujian Kualitas Karbon Aktif Ampas Tebu (Uji daya serap iod)}

Penetapan daya serap arang aktif terhadap iodin merupakan salah satu persyaratan utama untuk menilai kualitas arang aktif. Daya serap karbon aktif terhadap larutan iodin mengindikasikan kemampuan karbon aktif untuk mengadsorpsi komponen dengan berat molekul rendah. Selain itu daya serap terhadap iod juga menunjukkan kemampuan arang aktif dalam menyerap zat yang mempunyai ukuran molekul yang lebih kecil dari 10 Angstrom (Sudrajat, 2005).

Karbon aktif dengan kemampuan menyerap iodin yang tinggi berarti memiliki luas permukaan yang lebih besar dan memiliki struktur mikro yang lebih besar (Ikawati, 2010). Besarnya daya serap iodin berkaitan dengan terbentuknya pori pada arang aktif yang semakin banyak dengan bertambahnya waktu aktivasi.

Tabel 1. Data hasil uji daya serap iod

\begin{tabular}{|c|c|c|c|c|}
\hline No. & $\begin{array}{c}\text { Berat } \\
\text { sampel } \\
(\text { gram })\end{array}$ & $\begin{array}{c}\text { Volume } \\
\text { titrasi } \\
(\mathrm{ml})\end{array}$ & $\begin{array}{c}\text { Rata- } \\
\text { rata } \\
\text { volum } \\
\text { e (ml) }\end{array}$ & $\begin{array}{c}\text { Daya } \\
\text { serap iod } \\
(\mathrm{mg} / \mathrm{gr})\end{array}$ \\
\cline { 1 - 1 } 1 & \multirow{2}{*}{0.25} & 3.8 & \multirow{2}{*}{3.77} & \multirow{2}{*}{795.56} \\
\cline { 1 - 1 } 2 & & 3.9 & & \\
\cline { 1 - 1 } 3 & & 3.6 & & \\
& & &
\end{tabular}

Dari tabel 1 dapat dilihat bahwa hasil daya serap iodin oleh arang aktif ampas tebu yang diperoleh yaitu 795,56 mg/gram. Perhitungan ini dilakukan pengulangan sebanyak 3 kali untuk memperoleh data yang akurat. Hasil yang diperoleh telah mencapai Standar Nasional Indonesia No. 6-3730-1995 yaitu minimal sebesar $750 \mathrm{mg} / \mathrm{gram}$. Dengan demikian karbon aktif ampas tebu diharapkan dapat dijadikan adsorben untuk proses pemurnian minyak goreng bekas.

Selama proses adsorpsi, larutan iodin banyak yang masuk ke dalam pori karbon aktif dan teradsorpsi di permukaanya. Banyaknya iodin yang teradsorpsi oleh karbon aktif selanjutnya ditentukan sebagai angka iodin yang menyatakan banyaknya iodin yang mampu diadsorpsi oleh karbon aktif (mg/g). Banyaknya iodin yang diserap oleh karbon ditentukan dengan analisis filtrat sisa larutan iodin yang telah diasorpsi oleh karbon aktif. Larutan iodin sisa adsorpsi selanjutnya dititrasi dengan larutan $\mathrm{Na}_{2} \mathrm{~S}_{2} \mathrm{O}_{3} 0,1 \mathrm{~N}$. Iodin merupakan oksidator yang mampu mengoksidasi secara sempurna natrium tiosulfat yang bersifat reduktor kuat. Iodin yang dibebaskan selanjutnya dititrasi dengan larutan baku natrium tiosulfat $0,1 \mathrm{~N}$.

Iodin yang bebas dititrasi dengan natrium thiosulfat. Titik akhir titrasi pada penentuan angka iodin ini ditandai dengan munculnya warna kuning pucat pada larutan iodine. Pada analisisnya digunakan indikator amilum sebagai pewarnaan karena warna biru gelap dari 
kompleks iodin amilum bertindak sebagai suatu tes yang amat sensitif untuk iodin.

\section{Pemurnian Minyak Goreng Bekas}

Proses pemurnian minyak goreng bekas pada penelitian ini dilakukan 3 tahapan, yaitu: proses pemisahan bumbu (despicing), netralisasi dan pemucatan (bleaching) menggunakan karbon aktif ampas tebu.

\section{a. Proses Penghilangan Bumbu (Despicing)}

Despicing merupakan proses penghilangan bumbu dimana tahap pengolahan ini dilakukan dengan cara memanaskan minyak bekas yang telah ditambah dengan air dengan komposisi yang sama yaitu $(1: 1)$ pada suhu $110{ }^{\circ} \mathrm{C}$ hingga air tinggal setengahnya.

Kotoran-kotoran partikel halus tersuspensi seperti bumbu rempah-rempah dalam minyak goreng bekas akan larut dalam air dan ikut mengendap di atas permukaan air, sehingga pada proses ini diperoleh minyak bekas yang bebas bumbu. Dengan demikian senyawasenyawa pengotor polar dalam minyak goreng dapat diekstraksi ke dalam fase air, sehingga pada proses ini diperoleh minyak yang bebas bumbu, dengan warna minyak yang semula coklat gelap menjadi kuning kecoklatan.

Proses ini bertujuan untuk memisahkan partikel halus tersuspensi seperti protein, karbohidrat, garam, gula dan bumbu rempahrempah yang tertinggal dalam minyak ketika proses pemakaian berlangsung.

\section{b. Netralisasi}

Proses netralisasi adalah suatu proses untuk memisahkan asam lemak bebas dari minyak dengan cara mereaksikan minyak dengan basa sehingga membentuk sabun yang lebih larut dalam air. Kotoran dalam minyak seperti asam lemak bebas terperangkap pada sabun sehingga mudah memisahkan asam lemak bebas dalam minyak yang bersifat non polar.

Penelitian ini menggunakan $\mathrm{NaOH}$ sebagai pereaksi basa. Penggunaan $\mathrm{NaOH}$ membantu dalam mengurangi zat warna dan kotoran yang berupa getah serta lendir dalam minyak yang tidak dapat dihilangkan dengan proses despicing. Dengan proses netralisasi minyak, maka jumlah asam lemak bebas dalam minyak dapat dikurangi sampai kadar maksimum 0,2\%. Reaksi antara asam lemak bebas dengan $\mathrm{NaOH}$ adalah sebagai berikut:

Sabun yang terbentuk dapat membantu pemisahan zat warna dan kotoran seperti fosfatida dan protein dengan cara membentuk emulsi. Pada saat minyak goreng hasil despicing dicampurkan dengan larutan $\mathrm{NaOH} 16 \%$ yang dipercepat dengan pemanasan dan pengadukan akan terbentuk butiran kecil-kecil dan lamakelamaan warnanya berubah dari coklat menjadi orange tua. Minyak netral yang dihasilkan berwarna orange jernih dan bersih.

\section{c. Pemucatan (Bleaching): Adsorpsi minyak goreng bekas menggunakan adsorben karbon aktif ampas tebu}

Proses pemucatan (bleaching) merupakan proses pemurnian untuk menghilangkan zat-zat warna yang tidak disukai serta senyawasenyawa pengotor yang terkandung dalam minyak dengan menggunakan karbon aktif ampas tebu.

Minyak sawit merupakan salah satu minyak yang sulit untuk dipucatkan karena mengandung pigmen karotena yang tinggi sedangkan minyak biji-bijian lainnya lebih mudah karena zat warna yang dikandungnya sedikit. Oleh sebab itu, minyak sawit dipucatkan dengan kombinasi antara adsorben dengan pemanasan, minyak yang dihasilkan dengan cara ini memenuhi sebagai lemak pangan.

Penggunaan adsorben serta panas yang digunakan dalam proses pemucatan tidaklah selalu sama, tetapi tergantung pada kondisi minyak kelapa sawit dan sifat adsorben yang digunakan, umunya penggunaan adsorben adalah 1-5 \% dari berat minyak dengan pemanasan $120{ }^{\circ} \mathrm{C}$ selama $1 \mathrm{jam}$.

Pada penelitian ini, pemurnian dilakukan dengan cara mencampurkan $75 \mathrm{mg}$ adsorben karbon aktif ampas tebu ke dalam 100 gram minyak. Penambahan ini dilakukan pada saat minyak mencapai suhu $70{ }^{\circ} \mathrm{C}$, selanjutnya dilakukan pengadukan dengan magnetic stirrer 
selama 1 jam dan suhu ditingkatkan menjadi 100 ${ }^{\circ} \mathrm{C}$. Hal ini bertujuan untuk mempercepat reaksi antara adsorben dan adsorbat.

\section{Analisa Minyak Goreng}

\section{a. Penentuan Bilangan Peroksida}

Bilangan peroksida merupakan indikator terjadinya reaksi oksidasi pada tahap awal dan peringatan bahwa minyak sebentar lagi akan berbau tengik. Oksidasi oleh oksigen terjadi secara spontan pada saat minyak dibiarkan kontak dengan udara. Pada proses oksidasi terjadi penambahan molekul-molekul oksigen pada ikatan rangkap dari asam lemak tidak jenuh. Asam lemak pada umumnya semakin reaktif terhadap oksigen dengan bertambahnya jumlah ikatan rangkap pada rantai molekulnya. Molekul-molekul yang aktif dari minyak akan bereaksi dengan oksigen menghasilkan peroksida dan hidroperoksida, yang selanjutnya akan terkonversi menjadi aldehida, keton, dan asam lemak bebas. Rancidity (ketengikan) terbentuk oleh adanya aldehida, bukan terbentuk oleh adanya peroksida (Istighfaro, 2010).

Sejumlah minyak dilarutkan dalam campuran asetat:kloroform yang mengandung $\mathrm{KI}$, maka akan terjadi pelepasan iodin $\left(\mathrm{I}_{2}\right)$. Kloroform bersifat non polar dan asam asetat bersifat polar. Campuran keduanya adalah campuran pelarut polar dan non polar dapat melarutkan minyak goreng.

Iodin yang bebas dititrasi dengan natrium thiosulfat, selanjutnya ditambahkan indikator amilum sampai terbentuk warna biru, kemudian dititrasi lagi dengan natrium thiosulfat sampai warna biru hilang. Warna biru terbentuk, dikarenakan struktur molekul amilum yang berbentuk spiral mengikat molekul iodin (Arnas, Ika, 2010). Titrasi dilanjutkan sampai warna biru hilang.

Dari data hasil penelitian pada tabel 2 menunjukkan bahwa angka peroksida pada minyak goreng bekas sangat tinggi yaitu sebesar $10,12 \mathrm{meq} / \mathrm{kg}$. Hal ini disebabkan karena minyak goreng bekas yang digunakan adalah minyak yang sudah mengalami penggorengan selama lebih dari 5 jam sehingga menyebabkan minyak cukup banyak terpapar dengan oksigen.
Selain itu tingginya bilangan peroksida pada minyak goreng bekas ini disebabkan karena penyimpanan minyak goreng bekas yang dibiarkan pada wadah terbuka dalam waktu relatif lama.

Tabel 2 Data bilangan peroksida

\begin{tabular}{|c|c|c|c|c|}
\hline \multicolumn{5}{|c|}{ Rata-rata bilangan peroksida (meq/kg) } \\
\hline $\begin{array}{c}\text { Stan } \\
\text { dar } \\
\text { SNI }\end{array}$ & $\begin{array}{c}\text { Mi } \\
\text { nyak } \\
\text { goreng } \\
\text { bekas }\end{array}$ & $\begin{array}{c}\text { Minya } \\
\text { k hasil } \\
\text { despici } \\
\text { ng }\end{array}$ & $\begin{array}{c}\text { Minya } \\
\text { k hasil } \\
\text { netrali } \\
\text { sasi }\end{array}$ & $\begin{array}{c}\text { Minya } \\
\text { blea } \\
\text { ching }\end{array}$ \\
\hline $\begin{array}{c}\text { Maks. } \\
2\end{array}$ & 10,12 & 8,62 & 6,04 & 3,93 \\
\hline
\end{tabular}

Pada minyak hasil despicing, penurunan bilangan peroksida disebabkan karena senyawa peroksida R.COO ${ }^{\circ}$ dalam minyak goreng bekas memiliki gugus karboksil $\mathrm{RC}=\mathrm{O}$ dan radikal $\mathrm{O}^{\circ}$ yang lebih bersifat polar, dan memiliki rantai asam lemak oleat yang merupakan rantai karbon panjang yang lebih bersifat non polar (Istighfaro, 2010). Ketika minyak goreng dan air dipanaskan ada sebagian ikatan pada rantai karbon panjang yang putus sehingga memiliki rantai karbon pendek. Rantai karbon pendek R.COO ${ }^{\circ}$ ini akan lebih mudah larut dalam air panas dibanding dalam minyak. Air bersifat polar, sementara minyak bersifat non polar, karena beda kepolaran minyak dan air (tidak bisa larut) sehingga komponen polar yang ada dalam minyak bekas seperti protein, karbohidrat, garam, gula serta bumbu rempah-rempah yang berada dalam minyak larut dalam air, sehingga setelah melalui tahapan despicing angka peroksida mengalami penurunan.

Pada proses netralisasi, bilangan peroksida kembali mengalami penurunan. Hal ini disebabkan karena reaksi asam lemak bebas dengan larutan $\mathrm{NaOH}$ membentuk sabun. Kotoran dalam minyak seperti FFA dan peroksida tersebut terperangkap pada sabun sehingga mudah dipisahkan dari minyak yang bersifat non polar.

Pada proses bleaching, kembali terjadi hal yang sama yaitu penurunan bilangan peroksida. Adsorben karbon aktif ampas tebu dapat menurunkan angka peroksida dalam minyak goreng hasil netralisasi karena karbon aktif 
ampas tebu mempunyai kemampuan sebagai adsorben. Kemampuan karbon aktif ampas tebu sebagai adsorben tersebut dikarenakan adanya situs-situs aktif dalam karbon, seperti struktur kimia permukaan, susunan pori-pori dan luas permukaan adsorpsi yang terbentuk selama proses aktivasi, serta komposisi kimia permukaan yang ada dalam karbon aktif (Arnas, Ika, 2010).

Proses adsorpsi antara peroksida dengan karbon aktif ampas tebu dikarenakan adanya perbedaan energi potensial antara pemukaan karbon aktif ampas tebu dengan peroksida dalam minyak, baik itu melibatkan gaya fisika atau kimia. Interaksi antara peroksida dengan karbon aktif ampas tebu adalah adsorpsi secara fisika karena yakni setiap partikel-partikel adsorbat yang mendekati ke permukaan adsorben melalui gaya van der walls atau ikatan hidrogen, yakni melibatkan haya antarmolekuler. Namun demikian adsorpsi secara kimia juga dapat terjadi antara senyawa peroksida dengan gugus aktif yang dimiliki oleh karbon aktif ampas tebu. Pada proses adsorpsi kimia, interaksi antara adsorbat dengan adsorben melibatkan pembentukan ikatan kimia (biasanya ikatan kovalen).

Penurunan bilangan peroksida pada minyak goreng bekas, minyak hasil despicing, hasil netralisasi dan hasil bleaching menggunakan arang aktif dari ampas tebu dapat dilihat pada Gambar 1 berikut:

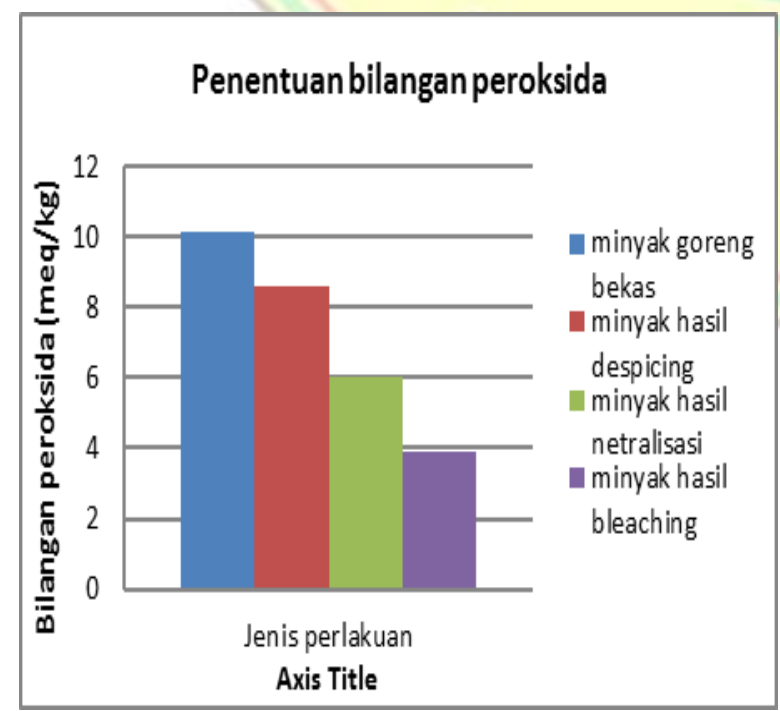

Gambar 1. Grafik perubahan bilangan peroksida
Rata-rata bilangan peroksida minyak goreng bekas, minyak hasil despicing, minyak hasil netralisasi, dan hasil bleaching pada tabel 3 berturut-turut 10,12 meq/kg, 8,62 meq/kg, 6,04 $\mathrm{meq} / \mathrm{kg}$, dan $3,93 \mathrm{meq} / \mathrm{kg}$. Hasil ini belum memenuhi standar kualitas minyak goreng (SNI) yaitu maksimal $2 \mathrm{meq} / \mathrm{kg}$.

Terdapat beberapa kemungkinan yang meyebabkan penyerapan oleh karbon aktif pada proses bleaching tidak memberikan hasil yang maksimal, diantaranya adalah adsorben karbon aktif telah mengalami penurunan daya adsorpsi karena telah terapar dengan udara. Karbon aktif bersifat higroskopis, sehingga penyimpanan sebelum digunakan harus dilakukan dengan sangat hati-hati dan dalam ruang kedap udara. Molekul air yang teradsorpsi jika karbon aktif terpapar dengan udara dapat mengurasi daya adsorpsi karbon aktif terhadap zat pengotor pada minyak goreng bekas.

\section{b. Penentuan Kadar Asam Lemak Bebas (FFA)}

Asam lemak bebas walaupun berada dalam jumlah kecil mengakibatkan rasa tidak lezat, menyebabkan karat dan warna gelap jika dipanaskan dalam wajan besi. Reaksi hidrolisis minyak atau lemak akan diubah menjadi asamasam lemak bebas dan gliserol. Reaksi ini dapat mengakibatkan kerusakan lemak atau minyak dan dipercepat dengan adanya panas, air, keasaman dan katalis (enzim).

Dari data hasil penelitian pada tabel 3 menunjukkan bahwa jumlah asam lemak bebas (FFA) pada minyak goreng bekas sangat tinggi yaitu sebesar $2,4 \%$, hal ini dikarenakan adanya proses oksidasi pada saat pemanasan, lama pemakaian dan penyimpanan. Adanya proses despicing, netralisasi dan bleaching membantu mengurangi senyawa-senyawa pengotor dalam minyak, sehingga karbon aktif banyak mengadsorpsi asam lemak bebas dalam minyak.

Pengaruh dan perubahan asam lemak bebas (FFA) dalam minyak bekas dengan perlakuan menggunakan adsorben karbon aktif kulit ampas tebu dapat dilihat pada tabel berikut: 
Tabel. 3 Data penentuan asam lemak bebas (FFA)

\begin{tabular}{|c|c|c|c|c|}
\hline & \multicolumn{4}{|c|}{ Rata-rata Asam Lemak Bebas } \\
(FFA) $\%$
\end{tabular}

Penurunan asam lemak bebas pada proses despicing disebabkan karena reaksi hidrolisis minyak dengan air, hal ini dikarenakan asam lemak bebas yang memiliki gugus karbonil dan gugus hidroksil yang bersifat polar akan larut dalam air dan bersamaan dengan air menguap pada proses pemanasan serta ikut terpisahkan pada proses pemisahan minyak dan air.

Penurunan asam lemak bebas pada proses netralisasi sama halnya dengan sebab penurunan bilangan peroksida, yakni karena asam lemak bebas bereaksi dengan $\mathrm{NaOH}$ yang bersifat basa membentuk sabun. Kotoran yang berupa asam lemak bebas ini dapat dengan mudah dipisahkan dari minyak yang bersifat non polar melalui proses penyaringan.

Pada proses bleaching, asam lemak bebas teradsorpsi oleh karbon aktif ampas tebu. Proses adsorpsi antara asam lemak bebas dengan karbon aktif ampas tebu dikarenakan adanya perbedaan potensial antara permukaan karbon aktif ampas tebu dengan asam lemak bebas, baik itu melibatkan gaya fisika atau kimia. Pada penelitian ini tidak dilakukan identifikasi terhadap gugus aktif pada karbon aktif ampas tebu, sehingga tidak dapat diketahui gugus aktif yang dimungkinkan untuk proses adsorpsi dengan gaya kimia. Pada proses bleaching ini, karbon aktif ampas tebu yang bersifat non polar mengadsorpsi asam lemak bebas yang juga bersifat non polar.

Penurunan jumlah asam lemak bebas (FFA) dapat dilihat pada grafik berikut:

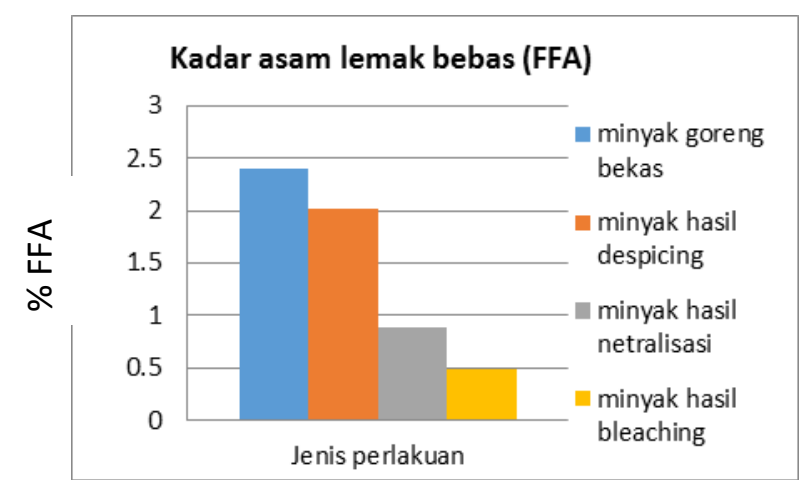

Gambar 2. Grafik perubahan jumlah asam lemak bebas

Rata-rata hasil penentuan jumlah asam lemak bebas (FFA) pada minyak goreng bekas, minyak hasil despicing, hasil netralisasi dan hasil bleaching berturut-turut adalah, 2,4 \%, $2,016 \%, 0,88 \%$, dan $0,49 \%$.

Adsorben karbon aktif yang digunakan pada penelitian ini sudah memenuhi standar SNI dalam hal daya jerap iod, semestinya kualitas yang baik ini dapat memberikan hasil yang lebih maksimal pada penurunan kadar asam lemak bebas. Namun hasil yang diperoleh belum memenuhi standar kualitas minyak goreng (SNI) yaitu maksimal 0,3\%. Karbon aktif sebelum digunakan haruslah disimpan dengan baik di dalam ruang kedap udara, kemungkinan yang terjadi adalah karbon aktif telah terpapar dengan udara sehingga mengadsorpsi molekul air yang menyebabkan penurunan daya adsorptivitasnya.

\section{DAFTAR PUSTAKA}

Tarigan, Novriani., Ida Nurhayati dan Riris Oppusunggu. 2007. Pengaruh Pemberian Penyuluhan Terhadap Angka Peroksida, Asam Lemak Bebas dan Suhu Penggorengan Minyak Goreng Pada Pedagang Makanan Jajanan Di Lubuk Pakam. Jurnal ilmiah PANNMED. Vol. 2 No. 1.

Arnas Puji Astutik, Ika. 2010. Pengaruh Suhu Interaksi Minyak Goreng Bekas Dengan Menggunakan Karbon Aktif Biji Kelor (Moringa oleifera. LAMK) Terhadap Angka Iodin dan Angka Peroksida. Skripsi. Jurusan kimia Fakultas Sains dan Teknologi Universitas Islam Negeri (UIN) Maulana Malik Ibrahim. Malang 
Buczek, Bronis dkk, 2008. Purification of the used palm oil by adsorption. Polish Journal of Chemical Technology, Cracow University of Economics, Departmen of General Chemistry, Faculty of Commodity Sciences, Poland.

Istighfaro, Nila. 2010. Peningkatan Kualitas Minyak Goreng Bekas dengan Metode Adsorpsi Menggunakan Bentolit-Karbon Aktif Biji Kelor (Moringa oleifera. Lamk). Skripsi Pada Program Sarjana. Jurusan Kimia, Fakultas Sains dan Teknologi, Universitas Maulana Malik Ibrahim, Malang.

Ketaren, S., (1986), Pengantar Teknologi Minyak dan Lemak Pangan, Penerbit Universitas Indonesia, Jakarta.

Mulawarman. 2007. Efektivitas Penggunaan Adsorben Kulit Pisang Keprok (Musa normalis) dalam Meningkatkan Kualitas Minyak Goreng Bekas. Jurnal Kimia Unmul. Vol. 4. Nomor 2. ISSN 16935616.

Tarigan, Novriani., Ida Nurhayati dan Riris Oppusunggu. 2007. Pengaruh Pemberian Penyuluhan Terhadap Angka Peroksida, Asam Lemak Bebas dan Suhu Penggorengan Minyak Goreng Pada Pedagang Makanan
Jajanan Di Lubuk Pakam. Jurnal ilmiah PANNMED. Vol. 2 No. 1.

Tri, Subeno Bambang., Porspek dan Tantangan Minyak Sawit Nasional. http://suaramerdeka.com/V1/index.php/r ead/cetak/2010/10/12/126470/Prospekdan-tantangan-Industri-Minyak-SawitNasional diakses 14 Februari 2011

Wahyuni, Sri dan Betty Kostradiyanti. 2008. Penurunan Angka Peroksida Minyak Kelapa Tradisional Dengan Adsoben Arang Sekam Padi IR 64 yang Diaktifkan Dengan Kalium Hidroksida. Jurnal Kimia FMIPA Universitas Udayana. ISSN 1907-9850.

Widayat, Suherman dan K Haryani. 2006. Optimasi Proses Adsorpsi Minyak Goreng Bekas Dengan Adsorben Zeolit Alam: Studi Pengurangan Bilangan Asam. Jurusan Teknik Kimia Fakultas Teknik Universitas Diponegoro, Semarang: Jurnal Teknik Gelegar Vol. 17, No 01.

Wijayanti, Ria. 2009. Arang Aktif Dari Ampas Tebu Sebagai Adsorben Pada Pemurnian Minyak Goreng Bekas. Skripsi Pada Program Sarjana. Departemen Kimia FMIPA, Institut Pertanian Bogor. 